\title{
ATTITUDE TO KORAN: CONTRADICTORY CHARACTER OF SECULAR AND DOGMATIC INTERPRETATIONS OF KORAN STATEMENTS
}

\author{
Vakhit Kh. Akaev \\ Russian academy of science. Grozny, Russian Federation \\ science-almanac@mail.ru
}

A contradictory, and often negative attitude toward Islam, its fundamental basis Koran, is formed in modern orientalistics. This is associated with an expressed tendency of Islam rejection, widely spread in the Western world. Active determination of this process became possible after the terrorist events of September 11,2001 in the USA. The splash of Islamophobia in the West was expressed in insulting remarks about Muhammad, the prophet of Muslims, his immoral images and provocative films shown in the media, on television. The extreme form of Islamophobia, demonstrated in the USA is the destruction the Koran of copies, which were publicly set on fire by some Christian priests. Specific facts reveal the level of Islamophobia in the United States, the mechanisms for its support and dissemination. Those who falsely prove that the Koran is a source of terrorism, while permitting arbitrary interpretations of its certain provisions, torn from the general context, were found in Russia after the terrorist events in the United States. The article substantiates the falsehood of this thesis, its superficial and harmful ideological character. The Islamophobic attitude of some Russian judges, who at first accepted and then annulled the decision about the Koran separate statements and Islamic texts, based on them to be extremist, is criticized. It is argued that in order to overcome Islamophobia, it is important to carry out a continuous dialogue between different religions, and scientists need to conduct joint studies that reveal common positions of the sacred text.

Key words: Islam, Muslims prophet, Koran, sura, ayats, islamophobia, priests, extremism, terrorism, dialogue, morally-humanitarian content of the sacred texts.

\section{[Акаев В.X. Отношение к Корану: противоречивый характер светских и догматических интер- претаций коранических положений]}

В современной ориенталистике, и в таком его направлении как исламоведение, формируется противоречивое, часто негативное отношение к исламу, его фундаментальной основе Корану. Это сопряжено с выраженной тенденцией неприятия ислама, широко распространяемой в западном мире. Активная детерминация этого процесса стала возможна после террористических событий 11 сентября 2001 года в США. Всплеск исламофобии на Западе выразился в оскорбительных высказываниях в адрес Мухаммада, пророка мусульман, безнравственных его изображениях и провокационных фрильмах, демонстрировавшихся в СМИ, на телевидении. Крайней формой исламофобии, продемонстрированной в США, является случаи уничтожения экземпляров Корана, которые публично поджигались некоторыми христианскими священниками. На конкретных фрактах раскрывается уровень исламофобии в США, механизмы его поддержки и распространения. После террористических событий в США, в России нашлись те, кто ложно доказывает, что Коран является источником терроризма, допуская при этом произвольные интерпретации отдельных его положений, вырванных из общего контекста. Обосновывается ошибочность данного тезиса, его поверхностный идеологический характер. Критикуется исламофоббкая позиция некоторых российских судей, принявших, а затем отменивших решения, о признании экстремистскими отдельные положения Корана и исламских текстов, основанных на них. Утверждается, что в целях преодоления исламофобии важно осуществление непрерывного диалога между разными религиями, а ученым необходимо проводить совместные исследования, выявляющие общие позиции священных текстов.

Ключевые слова: ислам, пророк мусульман, Коран, сура, аяты, исламофобия, священники, экстремизм, терроризм, диалог, нравственно-гуманистическое содержание священных текстов.

VakhitKh. Akaev - Ph.D. of philosophy, professor. Chief scientific worker of Comprehensive research institute of Russian academy of science, academician of Academy of science in Chechen Republic, expert of Russian academy of science. Grozny, Russian Federation. 
АкаевВахитХумидович - докторфилософоскихнаук, профрессор. Главный научный сотрудник КНИИ PAH, академик АН ЧР, эксперт РАН. е. Грозный, Россия.

The attitude problem towards the Koran and Islam in general in the West and in Russia has acquired a significant urgent character in connection with the events of September 11, 2001. Islamophobic mood sentiment degree increased significantly in the world mainly after these terrorist events. Journalists, politicians, statesmen, individual clergymen of the non-Islamic faith began to consider the Koran as a source of terrorism. A negative tendency, accusing the Koran in violence and even terrorism began to form in the domestic Islamic studies, presented by the works of secular scholars. This position with regard to the Koran was also chosen by certain law enforcement agencies that began to give judgments, trying to identify the presence of extremismfeatures in its separate provisions. A. Dvorkin [1] the former employee of the radio stations "The Voice of America" and "radio Freedom" the USA citizen, who came to Russia in 1991, significantly contributed to Islamophobia development. In many of his speeches, he admits not only a disdainful attitude towards Islam, but direct insults to the Prophet Muhammad.

Thus, in 2005, four years after the terrorist attack in New York, Washington, the book of the famous Russian religious scholar Yu.G. Petrash, where there is a 19 chapter, entitled as "Islam and Terrorism" was published [9. p, 301]. The author writes in the book that "the principles of gentiles decimation as the reason and justification of aggressive actions exist in the Koran (2:186-187), 189; 4: 91 and others"). In the ayats of these suras, called as "The Cow" and "Women" [7], the question is not about all the gentiles, but only about the pagans and those gentiles who violated the treaty with the Muslims, by taking the path of war with them. But Yu. G. Petrash, missing this essential detail, accuses the Koran of the fact that it admits the extermination of all the Gentiles. The author of the quoted book points to the unquestionably tragic events that took place in Beslan, connected with the seizure of the school by terrorists, the death of hundreds of children.He also affirms that the terrorists defended the principle of jihad in accordance with the tradition of the Koran: "beat the polytheists, capture them in places where they are found, besiege them, ambush them in any hidden place" (9:5).

However, the tragedy in Beslan, contrary to the author's statement, had nothing to do with jihad. In Sura 9 called "Repentance", only the polytheists are concerned, but the quoted author adds the expression "equal to other non-Muslims", thus permitting an arbitrary interpretation of the Quranic situation. Of all the verses of Sura 9, only ayat5 is analyzed, taken not completely and out of touch with the rest. Thus, in ayat 4, preceding ayat 5 , Muslims are required to observe the contract, concluded with the polytheists, and it is also forbidden to harm them. The author misses this point, there is a continuation in the ayate 5: "If they turned and performed the prayer and gave cleansing, then free the way for them: after all, Allah is Forgiving, Merciful". And the author does not quote, does not comment this part of the ayat. Meanwhile, the position of beating in the Koran is allowed against the polytheists, who do not follow either an oath or conditions in relation tothe Muslims (9:9).But the author does not take this into account.

At one of the conferences held at the Kazan Federal University in 2016, an employee of the African Studies Institute RAS, also stated that the Koran is a source of terrorism, referring to the verse 5 Surah 9. It would be good to mention, that in ayat 35(32) of 5 Sura, called as "Table Spread", fixing the relations of Avel and Kain - the sons of Adam, the God proclaims: who killed soul not for soul or not for spoiling on the earth, that as if killed all the people, but that who animated it,then as if animated all the people. The Koran also affirms that "but if somebody from polytheists asks for a shelter, then give a shelter for him, until he listens to the Allah word. Then take him to a safe place for him. This is because they 
are people who do not know". Domestic Islamist Taufik Ibrahim emphasizes that Sura 9 itself clearly demonstrates the "differentiated" approach. "Contrary to conformation about its total bellicosity, aggressive orientation, there, as before, it is clearly told that the war does not spread on pagans, who have not violated peaceful agreements with Muslims, but against those, who "first began to be at feud, expelled the Prophet, in relation to Muslims "Do not honor commitments and behave aggressively"[4, p. 201].

The same position is held by the American researcher John Esposito, who says that in the West "Islam is associated with cruelty and acts of terrorism, in fact, permissible cruelty is limited in it, and terrorism, attacks and hostage-taking are rejected based on the Koran, the laws of Islam establish the rules of war and prohibits acts of terror"[14, c. 217].

An important contribution was brought to the development of Islamophobia in Russia by A. Dvorkin [1], the former employee of the radio stations"Voice of America" and "Radio freedom", citizen of the USA. In many of his speeches, he admits not only a disdainful attitude toward Islam, but direct insults to the Prophet of the Muslims.

There are many statements, emphatically condemning the evil, violence, murder of the innocent people in the Koran. If this is so, then why is the Koran considered to be the source of terrorism? From our point of view, it is done consciously, its authors strive to recognize Islam as a universal evil and the main source of terrorism in the modern world. Muslims will never agree with this position, and they have a reason to do that.

Islamophobia is widespread in the United States. According to Said Faizan, executive director of the Council for US-Islamic Relations, the "inner core" of the American Islamophobia network was financed in the amount of almost 120 million \$ between 2008 and 2011. According to him, "the main purpose of these institutes and private individuals" is contained in slandering and attack against Islam, Muslims in the USA", and also with the goal of negative representation of the Muslims in the mass media. His composed report on 158 pages, called as "Fear", registered by the law: Islamophobia and its influence in the USA in 2011-2012", notes that 78 new bills and amendments, blur Islamic religious practices, and were introduced in legislative assemblies of 29 states for the last two years. It is also emphasized that at least in 11 states, the main republican leaders support antiMuslim legislation. It states that there are individuals and groups that have established institutions to attack Islam, Muslims and to generate fear in American society.

In the US, the level of Islamophobia has reached such proportions that the pastors of a number of non-denominational churches expressed and realized the idea of the Koran burning. It was first announced in July 2010 by the 58-year-old pastor of a small church in Florida, Terry Jones. He planned burning on September 11, 2010 from 6 to 9 pm. He collected 200 of the Koran copies for that. But with the help of the USA president Obama he was temporally dissuaded.

At that time, his idea was put into practice by other priests - two pastors from Tennessee - Bob Old and Danny Allen, who burned two editions of the Koran [11]. Several similar acts were committed in the streets of Manhattan, where earlier the twin towers of the World Trade Center were.The burning of the Koran caused an angry reaction in the Muslim countries, innocent people suffered and died.18 people were killed in the protesters clashes of demonstrators and police against the Koran burning in India. Protests with the death of people took place in Afghanistan, Egypt, Pakistan, Bangladesh, and others.

On the eve of the September 11next anniversary, in 2012 Jones declared this day as an international trial over the Prophet Muhammad, and hung his effigy in the courtyard of his church. This provocation, he accompanied a video message and text comment on his website, in which he claimed that the Muslim prophet Muhammad was guilty in the following:

- false prophecy, which misled about 1.6 billion people;

- incitement to murder, rape and robbery through the written Koran; 
- cruelty towards women, minorities, Christians and any non-Muslims, resulting in the death of 370 million people for 1400-year history of Islam [3].

The same American pastor in April 2013, who neverthelessmanaged to burnthe Koran copies, announced about plans to hallow the anniversary of the terrorist attack in 2001 by burning 2,998 of the Koran copies. In the evening of September 11, 2013, the pastor was detained by the police in Florida: 2,998 copies of the Koran (according to the number of the September 11 tragedy victims) were found in his lorry, doused with kerosene and prepared for burning [8]. The arrest of the pastor did not allow him to realize the conceived provocation.Antikoranic, anti-Islamic acts taking place in the United States have been specifically reflected in our country. Some of the Themis servants in Russia for some reason unexpectedly "inflamed" with the desire to realize prohibitionof certain Suras of the Koran in the judicial order.Thus, in May 2013, the decision of the Kirov District Court of the Bashkortostan Republic on the certain surasprohibition of the Koran was held. Extremists declared three surahs, "Bickering" (58:14 and 58:19), "Taha" (20:97), "Mumtahana" (60: 4) [10].

Two years after such decision, a court decision was made to recognize the book "Prayer (dua) for God its Purpose and Place in Islam" as an extremist in YuzhnoSakhalinsk[12]. This decision caused a massive outrage of the Muslims in Russia. The most acute was the statement of the Chechen Republic Head, R.A. Kadyrov, who called Judge Perchenko and Prosecutor Bilobrovets, who agreed to this decision as the national traitors and the shaitans[6]. He further proclaimed that "if they would not properly deal with it legally, then first of all they will make me a criminal. I personally will call them to account, because for me in this life there is nothing higher than the Koran". He demanded punishment for the provocateurs, who adopted the specified judicial decision, thereby trying to blow up the interreligious, ethnopolitical situation in Russia.

It should be noted that with careful reading of the abovementioned ayats of the Koran, I personally could not find in them what is classified as extremism in Russian jurisprudence. And I regard this fact as a graphic example of an artificially created legal incident. It seems that such incidents could not stop, if the Russian Federation State Duma would have not adoptedthe bill, prohibiting the recognition of sacredtexts chapters of Christians, Muslims, Jews and Buddhists to be extremist[2].

In 2013, the US "Center for American Progress" (CAP), close to the administration of President Obama, published a report entitled "Fear incorporated: The network roots of the Islamophobia in America". It establishes 7 associations that secretly transferred 42 million \$ to individuals and organizations that led a nationwide anti-Muslim campaign in 2001-2009. A list of anti-Islamic associations, research centers, politicians, journalists, bloggers who purposefully propagate Islamophobia in the United States following the September 11 attacks is provided.

Among these associations there are as ultra-right, so individual family Jewish groups. "Islameaters" - representatives, disinforming the citizens about Islam on the television and radio, proclaiming about the treat, allegedly originating from the USA national security are enumerated.This list includes personalities such as Frank Gaffney from the "Center for Security Policy", Daniel Pipes from the "Middle East Forum", Stephen Emerson from the "Project on the Terrorism Investigation", David Yerushalmi from the "American Society for a National Existence", Robert Spencer from organizations "Stop Islamization of America" and others[15].

Trump retwitted on his page three posts on 29 of November, which were placed at the British political party leader page "Britain First"Jayda Fransen. This activist was arrested in the center of Belfast for anti-Islamic speech in the end of November of the same year.Moreover, the current US president published a video under the titles "A crowd of Islamists pushed the boy from the roof and beat him to death", "A Muslim destroyed the sta- 
tue of the Virgin Mary" and "A Muslim Migrant beat a teenager on crutches". Thus, President Trump now pushes as a bright leader of Islamophobia in the US, which may well have a negative impact on the Muslims of this country.

During his visit to Saudi Arabia, UN Secretary-General Antonio Guterres stated that it is Islamophobia that promotes the incitement of terrorism.After speaking with the King of this country Salman bin Abdulaziz, the Minister of the Interior and his deputy, speaking to reporters, he said: "One of the things that foments terrorism is a manifestation of Islamophobic feelings, Islamophobic politics and Islamophobic rhetoric in some parts of the world" [5].

In this regard, the question is being raised whether the new UN leader will be able to overcome or minimize European Islamophobia.

In this connection, I believe that the Koran allows the same mutual respect for the highest spiritual values of different human communities[13, p. 1049]. In this regard, it is necessary to develop a counteraction system to various forms of manifestation of religious radicalism and extremism, thoroughly studying the peaceful, humanistic, spiritual moral basis of the Koran and Islam in general in the Islamic educational institutions in our country.

It seems necessary for Muslims to be in constant creative dialogue with other faiths, representatives of other cultures and civilizations. In this regard, it is necessary to carry out purposeful activities of the Muslims themselves, their ulemas, secular scholars, the media. It is necessary to hold the international forums with the of all beliefs representatives participation, discussing the problems of the coexistence of people, religions, cultures, civilizations, their present and future. It seems necessary to actively carry out joint, purposeful research by Islamic and secular scholars for a thorough study of the Koran, revealing its spiritual, moral, humanistic basis, comparing them with the similar values of other scriptures. It is important at the same time to widely spread the results of such joint research.

\section{Лumepamypa}

1. Главный сектовед России - Саша Дворкин - фральшивый профессор из США // http://oleglurie-new.livejournal.com/309963.html

2. Госдума запретила искать экстремизм в Коране и Библии http://www.thevillage.ru/village/city/situation/225793-iskat-ekstremizm-v-korane

3. Джонс Терри (пастор) https://ru.wikipedia.org/wiki/\%D0\%94\%D0\%B6\%D0\%

4. Ибрагим Кемаль Тауфик. Коранический гуманизм. Толерантноплюралистические установки. Москва: Медина, 2015.

5. Ислам для всех. 2017. 14 февраля.

6. Кадыров пригрозил расправой судье и прокурору в Южно-Сахалинске // https://meduza.io/news/2015/09/09/kadyrov-prigrozil-raspravoy-sudie-i-prokuroru-vyuzhno-sahalinske

7. Коран. Пер. с араб. акад. И. Ю. Крачковского. М.: Раритет, 1990.

8. Пастор Терри Джонс арестован при попытке сжечь 3 тысячи копий Корана // https://ria.ru/world/20130912/962579710.html

9. Петраш Ю.Г. Ислам: происхождение, вероучение современность (философско-культурологический взгляд). М.: Республика, 2005.

10. Рахматов Рамиль. В Башкирии в сурах Корана пытаются углядеть экстремизм// http://archiv.proufu.ru/obcestvo/item/26129-koran-pod-sudom-v-bashkiriisozdaetsya-opasnyj-pretsedent.html

11.Стасюк И. Священники провозгласили ислам лжерелигией // http://news.tochka.net/51740-v-ssha-vse-taki-sozhgli-koran-foto/ 
12. Судья запретила фрразы из Корана на основании экспертизы МВД // https://life.ru/t/\%D0\%BD\%D0\%BE\%D0\%B2\%D0\%BE\%D1\%81\%D1\%82\%D0\%B8/ 161156

13. Ходжсон Маршалл. История ислама: Исламская цивилизация от рождения до наших дней. М.: Эксмо, 2013.

14. ЭспозитоДж. Почемумусульманетакие.М.: Эксмо, 2011.

15. AkayevV.Kh. Islam in modern Russia: interrelation of traditions and innovations // НаучныйальманахстранПричерноморья. 2015. № 3.http://science-almanac.ru

16. AkaevV.Kh. Ethnocultural diversity and consolidation of Caucasus people unity: theoretic-methodologic analysis // НаучныйальманахстранПричерноморья. 2016. № 3. http://science-almanac.ru

\section{References}

1. The main sect leader in Russia -Sasha Dvorkin-the false professor from the USA // http://oleglurie-new.livejournal.com/309963.html

2. The State Duma has forbidden to seek extremism in the Koran and the Bible // http://www.the-village.ru/village/city/situation/225793-iskat-ekstremizm-v-korane

3. JonesTerry (pastor). https://ru.wikipedia.org/wiki/\%D0\%94\%D0\%B6\%D0\%

4. Ibrahim Kemal Taufik. KoranHumanism. Tolerant-pluralistic attitudes.Moscow: Medina, 2015.

5. Islam for everybody. 2017. 14 of February.

6. Kadyrov threatened to punish the judge and the prosecutor in Yuzhno-Sakhalinsk // https://meduza.io/news/2015/09/09/kadyrov-prigrozil-raspravoy-sudie-i-prokuroru-vyuzhno-sahalinske

7. Koran. Trans. from Arabic. Academ. I. Yu. Krachkovsky. M.: Raritet, 1990.

8. Pastor Terry Jones is arrested while trying to burn 3,000 of the Koran copies // https://ria.ru/world/20130912/962579710.html

9. PetrashYu.G. Islam: origins, creed, modernity (Philosophic-culturological view). M.: Republic, 2005.

10. RakhmatovRamil. One tries to catch the extremism in the Suras of the Koran in Bashkortostan. http://archiv.proufu.ru/obcestvo/item/26129-koran-pod-sudom-vbashkirii-sozdaetsya-opasnyj-pretsedent.html

11. Stasyuk I. Priests proclaimed Islam as false religion // http://news.tochka.net/51740v-ssha-vse-taki-sozhgli-koran-foto/

12. The judge has forbidden phrases from the Koran on the basis of the MIA expertise /I

https://life.ru/t/\%D0\%BD\%D0\%BE\%D0\%B2\%D0\%BE\%D1\%81\%D1\%82\%D0\%B8/ 161156

13. Hodgson Marshall. History of Islam: Islamic civilization from birth to the present day. M.: Eksmo, 2013.

14. Esposito J. Why are Muslims such people.M.: Eksmo, 2011.

15. AkayevV.Kh.Islam in modern Russia: interrelation of traditions and innovations // Scientific almanac of the Black sea region countries. 2015. No 3. http://sciencealmanac.ru

16. AkaevV.Kh.Ethnocultural diversity and consolidation of Caucasus people unity: theoretic-methodologic analysis //Scientific almanac of the Black sea region countries. 2016. No 3. http://science-almanac.ru 